\title{
Optical fluorescent instrumentation developement suitable for cell based biosensor
}

\author{
Totok Mujiono*) dan Tasripan \\ Jurusan Teknik Elektro FTE- ITS
}

totok_m@ee.its.ac.id *)

\begin{abstract}
Abstrak
Biosensor semakin mendapat perhatian dari para peneliti akhir-akhir ini terutama karena memiliki kelebihan dalam hal selektivitas dan sensitivitasnya. Biosensor ditemukan di banyak bidang aplikasi terutama untuk kesehatan dan keamanan makanan. Biosensor terdiri dari bioreceptor dan transduser. Salah satu jenis bioreceptor dan transdusernya yang sedang berkembang adalah biosensor berbasis sel dengan transduser fluoresens optik. Di antara kelebihan transduser fluoresen optik adalah perangkat yang tidak invasif dan tidak memerlukan probe yang sering menyebabkan kesulitan karena ukuran bioreceptor yang sangat kecil. Instrumentasi fluoresens optik pada dasarnya terdiri dari sumber cahaya untuk eksitasi, beberapa perangkat optik untuk membimbing cahaya dan detektor foto untuk menangkap fluoresen yang dipancarkan. Makalah ini membahas instrumentasi fluoresens untuk sensor bau berbasis sel. Sensor memiliki kepekaan terhadap eksitasi cahaya biru dan mengemisikan cahaya hijau. Ketika sensor berinteraksi dengan bau tertentu, intensitas emisi akan meningkat dengan bertambahnya intensitas bau. Hasil pengukuran menunjukkan bahwa instrumentasi fluoescent optik yang dikembangkan dapat digunakan sebagai transduser untuk bioelemen berbasis sel secara efisien.
\end{abstract}

Kata Kunci: biosensor; instrumentasi fluorescenl; bioreceptor sel.

\section{Introduction}

Sensor berdasarkan fenomena biologis (sensor biologi atau biosensor) saat ini mendapatkan lebih banyak perhatian karena kinerjanya diperkirakan melebihi sensor jenis yang lain seperti sensor kimia atau fisika. Seekor anjing dapat mendeteksi aroma jauh lebih akurat dan lebih cepat dibandingkan dengan sensor buatan yang ada saat ini. Biosensor terdiri dari dua bagian, elemen penginderaan (sensing) dan transduser. Bagian penginderaan merupakan elemen biologi (bioreceptor) yang merespons rangsangan dari luar seperti suhu, kelembaban, bau, dan sebagainya. Sementara transduser digunakan untuk mengubah sinyal biologi yang dihasilkan bioreceptor untuk diubah menjadi sinyal fisik seperti listrik dan optik.

Ada banyak elemen biologi yang dapat digunakan sebagai bioreceptor seperti enzim, antibodi, sel, jaringan, organ dan sebagainya. Misalnya, dalam biosensor berbasis sel, sel hidup digunakan untuk mengekspresikan reseptor penciuman (OR) dan digunakan sebagai elemen penginderaan. Biosensor berbasis sel memiliki potensi memberikan keuntungan dengan sensitivitas tinggi, respon cepat dan biaya rendah [1].

Beberapa teknik dapat digunakan untuk mengubah sinyal biologis menjadi sinyal listrik seperti elektrokimia, optik, akustik, teknik kolorimetri, dan lain-lain. Sebagai contoh, sel Xenopus oocyte yang mengekspresikan reseptor penciuman (OR) dengan transduser amperometrik berhasil digunakan sebagai sensor bau [2]. Penelitian pada paper ini membutuhkan elektroda yang ditusukkan ke dalam sel (teknik invasif) sehingga sel mudah rusak dan rentang hidup sel menjadi pendek. Untuk itu, teknik non-invasif perlu dikembangkan karena dimensi sel yang sangat kecil dan mudah rusak. Salah satu teknik noninvasif adalah menggunakan transducer fluoresens optik. Transducer jenis ini pada dasarnya memanfaatkan fenomena fluoresen dengan memanfaatkan komponen optik [3]. Teknik fluoresen adalah salah satu teknik optik non-invasif yang cocok untuk sistem penginderaan berbasis sel [4].

\section{Sistem Biosensor}

\subsection{Bioreceptor sel}

Gambar 1 menunjukkan ilustrasi sebuah bioreceptor sel. Sel Sf21 yang mengekspresikan reseptor bau atau olfactory receptor (OR) dan protein fluoresen GCaMP3 [5]. Diameter dari sel Sf21 dalah sekitar $20 \mu \mathrm{m}$. Pada sel tersebut OR, pompa PMCA dan protein fluoresens. OR berfungsi sebagai kanal ion (kalsium) yang akan mengalirkan ion kalsium masuk ke dalam sel jika ditriger oleh molekul bau (odoran). Protein fluoresent GCaMP3 akan mengemisikan sinar hijau dengan panjang gelombang 516nm ketika menerima sinar emisi biru dengan panjang gelombang 491nm. Untuk sinar eksitasi dengan intensitas yang sama, intensitas sinar emisi yang bergantung pada konsentrasi ion kalsium $\left(\mathrm{Ca}^{2+}\right)$ disekitarnya. Semakin besar konsentrasi ion kalsum akan semakin besar pula emisi yang dihasilkan. Pompa PMCA (plasma membrane $\mathrm{Ca}^{2+}$ 
ATPase) akan memompa kalsium ion keluar sel apabila konsentrasinya melebihi normal.

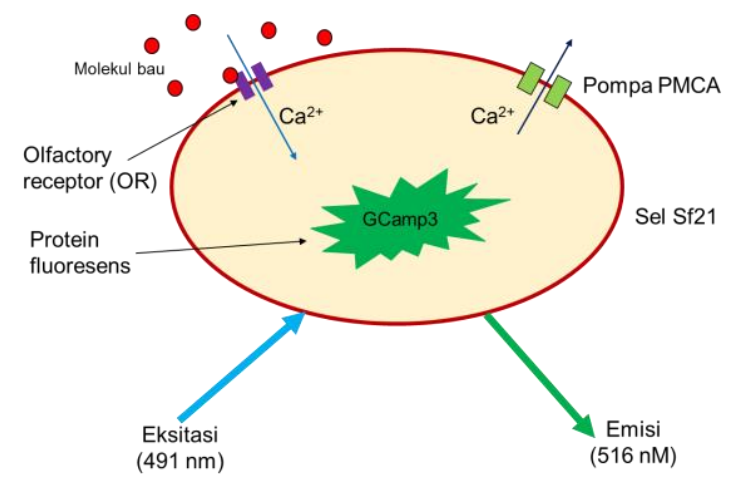

Figure 1 Sel sebagai bioreceptor.

Pada saat OR mengikat molekul bau, kanal ion akan terbuka dan menyebabkan ion kalsium masuk kedalam sel (Gambar 1) sehingga menyebabkan konsentrasi ion kalsium dalam sel meningkat. Semakin banyak konsentrasi molekul bau akan semakin banyak ion kalsium yang masuk karena ada banyak OR (kanal) pada dinding sel. Untuk memantau konsentrasi atau aktivitas ion kalsium dalam sel digunakan protein fluorescens dari jenis GCaMP3. Semakin besar konsentrasi ion kalsium dalam sel akan menyebabkan intensitas sinar emisi meningkat apabila mendapatkan sinar eksitasi. Emisi cahaya yang dikeluarkan sel dipantau oleh instrumentasi optik. Metode fluoresens optik terbukti cocok untuk aplikasi dengan sensitivitas tinggi dan untuk miniaturisasi perangkat.

\subsection{Instrimentasi fluoresens}

Fluoresensi adalah emisi cahaya oleh suatu zat yang telah menyerap cahaya atau radiasi elektromagnetik lainnya. Instrumentasi fluoresensi memanfaatkan fenomena di mana panjang gelombang cahaya yang dipancarkan (emisi) oleh sampel lebih panjang daripada panjang gelombang cahaya yang diserap (eksitasi). Pergeseran panjang gelombang ini dikenal sebagai pergeseran Stokes dan memungkinkan pemisahan kedua macam cahaya tersebut menggunakan optik yang sesuai. Instrumentasi fluoresens standar terdiri atas sumber cahaya eksitasi, filter, lensa, cermin dichroic, meja sampel, dan sensor optik. Teknik fluoresensi digunakan di banyak area aplikasi. Sistem hidung artifisial berbasis fluoresensi yang menggabungkan sensor serat optik sebagai elemen sensor telah dikembangkan [6].
Skema dasar instrumentasi fluoresens ditunjukkan oleh gambar 2. Sinar eksitasi biru yang dihasilkan oleh sistem laser dikonsentrasikan menggunakan lensa kolimator dan kemudian difilter (filter eksitasi) untuk memungkinkan hanya cahaya dengan panjang gelombang warna biru untuk melewatinya. Panjang fokus lensa kolimator adalah $3,41 \mathrm{~mm}$. Sinar eksitasi biru ini kemudian dipantulkan oleh cermin dichroic dan diarahkan ke lensa objektif untuk dipusatkan pada sel. Cermin dichroic dipilih dan ditempatkan sehingga dapat memandu cahaya biru dari sistem laser untuk ditujukan kearah sel.

Karena mendapatkan eksitasi, sel akan mengemisikan cahaya hijau. Lensa objektif dengan pembesaran (M) dan fokus masing-masing 10 dan $18 \mathrm{~mm}$ ditempatkan di depan sel. Lensa objektif dengan pembesaran yang tepat diperlukan karena ukuran sel kecil $(20 \mu \mathrm{m})$. Filter optik hijau (filter emisi) ditempatkan untuk melewatkan hanya cahaya hijau sebelum ditangkap oleh kamera. Karakteristik filter eksitasi, lensa dichroic, dan filter emisi ditunjukkan oleh Gambar 3.

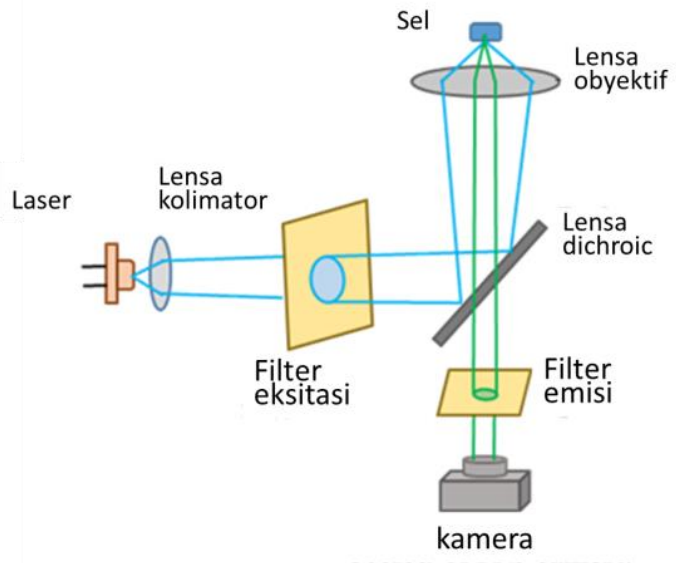

Figure 2 Blok diagram instrumentasi fluoresens

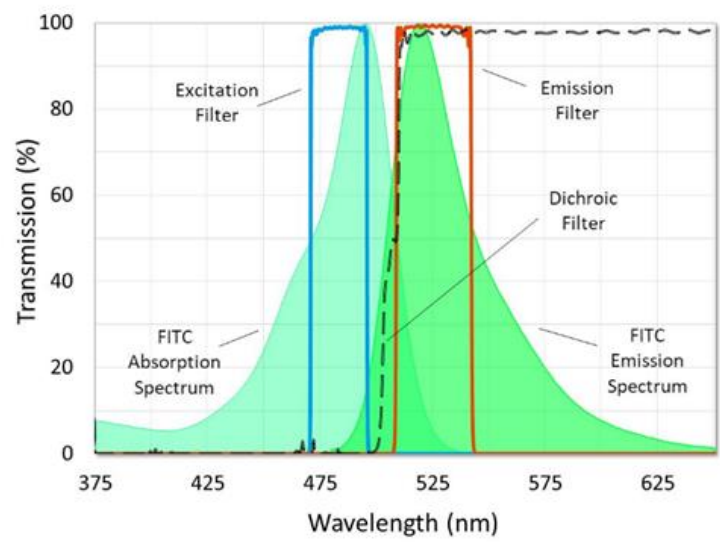

Figure 2 Karakteristik filter eksitasi, lensa dichroic, dan filter emisi [7] 
Dalam merancang instrumentasi fluoresens, jarak panjang fokus kedua lensa objektif $\left(f_{o b j}\right)$ dan lensa kolimator $\left(f_{c o l}\right)$ harus ditentukan secara tepat, $f_{c o l}$ perlu disesuaikan untuk sinar laser yang tepat sementara $f_{\text {obj }}$ perlu disesuaikan untuk mendapatkan gambar yang jelas. $f_{\text {col }}$ adalah jarak antara dioda laser dan lensa kolimator sedangkan $\mathrm{f}_{\text {obj }}$ adalah jarak antara objek (sel) dan lensa objektif.

\section{Uji coba dan diskusi}

Uji coba dilakukan dengan mengamati intensitas cahaya fluoresens hijau yang diemisikan oleh sel. Pengamatan dilakukan dalam kondisi gelap dimana instrumentasi fluoresens diletakkan dalam kotak hitam. Pengamatan dilakukan baik sebelum dan setelah bau (geosmin) diberikan. Gambar 4 menunjukkan gambar yang ditangkap kamera sesaat setelah bau diberikan kepada sensor. Setiap bulatan kecil adalah sebuah sel. Diameter sel lebih kurang 20 micrometer. Dari Gambar 4 dapat dilihat bahwa intensitas dari emisi yang dihasilkan tidak merata. Hal ini disebabkan oleh tidak atau belum meratanya konsentrasi molekul bau diantara sel-sel sensor.

Gambar 5 menunjukkan kurva intensitas terhadap waktu. Intensitas cahaya fluoresens merupakan gabungan (resultan) dari semua cahaya fluoresens yang dihasilkan oleh sel-sel yang dapat ditangkap oleh kamera. Intensitas cahaya fluoresens dinormalisasi terhadap intensitas pada awal pengamatan ( $\mathrm{t}=0$ detik) sehingga pada $\mathrm{t}=0$ kurva intensitas bernilai 1 . Pada $t=5$ detik, bau geosmin diberikan pada sensor. Beberapa saat setelah diberikan bau, sensor merespons dengan naiknya intensitas cahaya fluoresens sampai mencapai puncaknya pada $\mathrm{t}=28$ detik dimana besarnya intensitas adalah sebesar lebih kurang 1,25. Pada kondisi ini terjadi kenaikan intensitas kira-kira sebesar $25 \%$, sebelum akhirnya menurun karena konsentrasi ion kalsium damal sel menurun

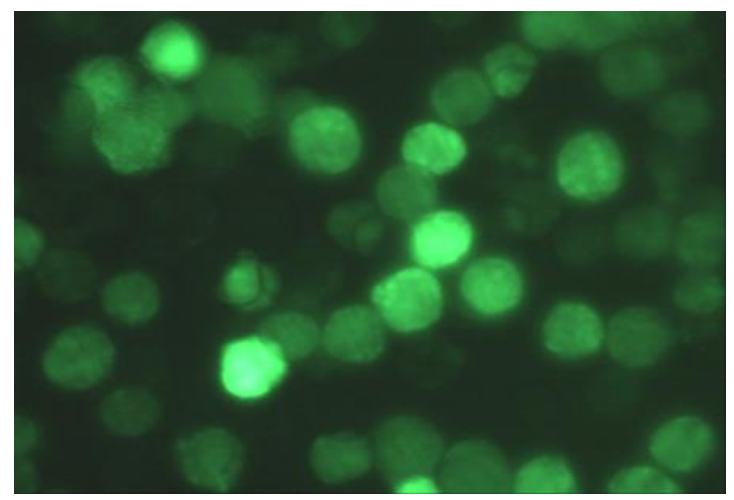

Gambar 4 Gambar sel-sel yang ditangkap kamera

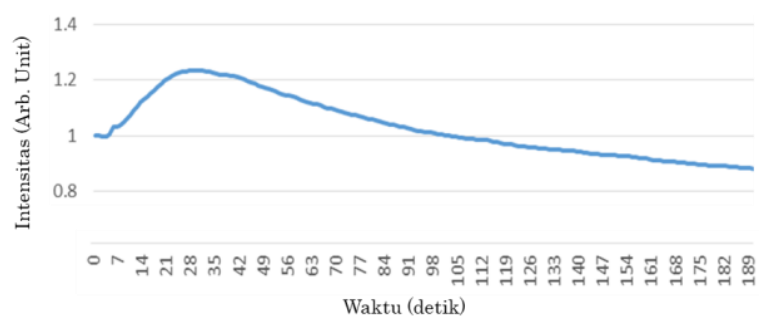

Gambar 4 Respon sensor terhadap waktu

Menurunnya intensitas cahaya fluoresens adalah akibat berkurangnya konsentrasi ion kalsium dalam sel akibat aktifnya pompa PMCA (Lihat Gambar 1). Pompa PMCA ini akan aktif secara otomatis apabila konsentrasi ion kalsium dalam lebih besar dari nilai normalnya. Namun demikian, intensitas intensitas cahaya fluoresens terus menurun dibawah nilai 1 . Hal ini adalah akibat efek photobleaching karena terpaparnya sel oleh sinar laser cukup lama sehingga mempengaruhi kemampuan fluoresensi dari sel. Pengaruh photobleaching dapat dikurangi dengan mengurangi intensitas sinar eksitasi. Sebagai konsekuensi dari pengurangan intensitas sinar eksitasi, akan mengurangi sensitivitas dari sensor.

\section{Kesimpulan dan saran}

Dari pembahasan yang telah dilakukan, biosensor dengan menggunakan bioreceptor sel yang telah dimodifikasi melalui teknik dibidang bioteknologi yang digabungkan dengan transducer optik telah dilakukan. Hasil pengamatan menunjukkan biosensor dapat merespon bau geosmin dengan baik. Namun demikian, penelitian lebih lanjut perlu dilakukan untuk melakukan kuantisasi terhadap konsentrasi dari bau tersebut. Setelah itu, perlu dilakukan kalibrasi terhadap alat yang dibuat sehingga dapat digunakan untuk melakukan pengukuran. Eksperimen menggunakan alat ini dilakukan pada malam hari atau didalam kotak hitam (black box). Hal ini dilakukan untuk menghindari cahaya selain warna hijau masuk. Intensitas cahaya luar ini jauh lebih besar dari emisi fluoresens. Supaya alat ini dapat dipakai pada kondisi biasa (tidak dalam kamar gelap atau black box) perlu ditambahkan teknik yang lain misalnya lock-in amplifier [8].

\section{Ucapan terima kasih}

Terima kasih kepada Prof. Takamichi Nakamoto dari Institut Teknologi Tokyo dan Prof. Ryohei Kanzaki dari Universitas Tokyo yang telah memberikan fasilitas untuk penelitian ini. 


\section{Refference}

[1] R. Monosika, M. Stredanskyb, E. Sturdik, "Biosensors-classification, characterization and new trends", Acta Chimica Slovaca, Vol. 5, No. 1, 2012, pp. 109-120.

[2] N. Misawa, H. Mitsuno, R. Kanzaki, and S. Takeuchi, "Highly sensitive and selective odorant sensor using living cells expressing insect olfactory receptors", PNAS, Vol. 107, pp. 15340-15344 (2010).

[3] Jennifer C. Walters, "Accuracy and precissin in quantitative fluorescence microscopy", J. Cell Bio. Vol. 185 No 7, pp 1135-1148 (2009).

[4] T. Mujiono, Y. Sukekawa. T. Nakamoto, H. Mitsuno, R. Kanzaki, N. Misawa, "Odor sensing method using olfactory receptors and fluorescent instrumentation", Proceeding of the 2015 ASCC - Kota Kinabalu (Malaysia), May 31 - June 3.
[5] H. Mitsuno, T. Sakurai, S. Namiki, H. Mitsuhashi, and R. Kanzaki, "Novel cell-based odorant sensor elements based on insect odorant receptors", Biosensor and Bioelectronics, Vol. 65, pp. 287-294 (2015).

[6] Matthew J. Aernecke, David R. Walt, Opticalfiber arrays for vapor sensing, Volume 142, Issue 2, 5 November 2009, Pages 464-469.

[7] https://www.alluxa.com/learningcenter/optical-filter-applications/fluorescencefilters-microscopy-imaging/

[8] T. Mujiono, T. Nakamoto, Y. Sukekawa, H. Mitsuno, R. Kanzaki, N. Misawa. "A Cell-Based Odor Sensing System Using Fluorescent Technique and Lock-in Measurement Robust Against Disturbance", IEEE Sensors 2015, Nov. 2015. 